\title{
Acute and subacute toxicity evaluation of hydroalcoholic extract of Caryota urens leaves in Wistar rats
}

\author{
Sujitha Balaji, Kripa Kavasseri Ganesan* \\ Department of Biochemistry, VISTAS, Chennai 600 117, India.
}

\begin{tabular}{l}
\hline ARTICLE INFO \\
\hline Received on: $30 / 11 / 2019$ \\
Accepted on: $29 / 01 / 2020$ \\
Available online: $04 / 04 / 2020$ \\
\\
\hline Key words: \\
Caryota urens, acute toxicity, \\
subacute toxicity, Wistar rats, \\
herbal medicine.
\end{tabular}

\begin{abstract}
Caryota urens native to Srilanka and India grows in tropical and subtropical regions. It is rich in nutrition and show pharmacological properties owing to the presence of flavonoids, coumarins, carbohydrates, and amino acids. However, scientific reports which guarantee the safety of $C$. urens are not available. Therefore, the intention of the current investigation was to assess the potential toxicity of the hydroalcoholic extract of C. urens leaves (CULHA) in Wistar rats. In acute toxicity study, CULHA was administered at a single oral dose of $2,000 \mathrm{mg} / \mathrm{kg}$ body weight. In subacute toxicity study, CULHA was administered once a day at three dose levels of 100, 200, and $400 \mathrm{mg} /$ $\mathrm{kg}$ body weight for 28 days. At the end of the treatment, animals were sacrificed; vital organs were removed and examined histopathologically. Blood and serum samples were collected and processed immediately for the analysis of hematological and biochemical parameters. During acute toxicity study, treatment-associated death or manifestation of toxic clinical symptoms were not seen. Furthermore, results of both acute and subacute toxicity group exposed to CULHA did not exhibit significant change in hematology, biochemical parameters, and histopathology. The results demonstrated that CULHA did not possess potential to induce toxicity.
\end{abstract}

\section{INTRODUCTION}

In India, plant and plant products are part of a healthcare scheme since 5,000 years. In olden literature like Rig veda, the use of plants and herbal formulations as medicine has been documented (Varshney and Suresh, 2015). The research has confirmed the clinical usefulness of several herbs against diseases for which modern therapy is ineffective or has associated side effects.

A recent survey by World Health Organization, reports that roughly $70 \%-80 \%$ of the people in the developing nations relies on conventional medicine for their primary healthcare (Oyebode et al., 2016). Using natural resources for healthcare is developed based on routine experience. A significant number of the population has used medicinal plants at least once for healthcare. Substantial increase in the popularity of herbal medicine is based on the trust that these medications are natural and, therefore,

\section{${ }^{*}$ Corresponding Author}

Kripa Kavasseri Ganesan, Department of Biochemistry,

VISTAS, Chennai 600 117, India.E-mail: kripasiva06@yahoo.co.in not likely to harm and a feeling of better control over disease management. In addition, in most of the countries there are no restrictions upon herbal products, and therefore access to herbal medicines are easier and unlimited (Woo and El-Nezami, 2017). However, various types of medicinal herbs used in traditional societies have been linked with toxic adverse effects (Dominic, 1999). Therefore, in order to develop and launch the safety and efficacy of a new drug, pre-clinical trials are very essential in animal models ( Jothy et al., 2011; Moreira et al., 2014).

Caryota urens native to Srilanka and India grows in tropical and subtropical regions. It is commonly called as wine palm or jaggery palm (Deepakkumar, 2016). The palm tree is famous for its Kitul syrup from flowers. Recent scientific reports say the syrup is rich in nutrition as it contains reducing sugars (Hall, 1995). In Ayurvedic medicine, it is used in the treatment of rheumatic swellings, snake bites, and tooth decay (Chauhan Gayatri and Gadhvi, 2018). Recently, our group has shown that the CULHA exhibits significant antioxidant activity in in vitro models and this activity was found to be associated with its high flavonoid and phenol content (Sujitha and Kripa, 2018). Several other studies have also highlighted the antioxidant property of 
C. urens due to the presence of phytochemicals (Arul Ananth et al., 2013; Ranasinghe et al., 2012). Despite the fact that the C. urens is well known for its therapeutic activity in traditional communities, no data is available on its safety and efficacy. Hence, the current study is focused on evaluating the safety profile of $C$. urens in male and female Wistar rats using hematological, biochemical, and histopathological parameters.

\section{METHODS}

\section{Preparation of plant material}

Caryota urens used in this study was collected from VISTAS campus, Chennai in December, 2016. It was authenticated (PARC/2016/3315) by plant taxonomist Dr. J. Jeyaraman, Plant Anatomy Research Centre (PARC), Tambaram, Chennai-600045.

Plant material was washed to remove any dirt and dried under shade for 15 days. The dried plant material was made into coarse powder using a mixer grinder and was further subjected to extraction procedures.

$200 \mathrm{~g}$ of the C. urens leaf was immersed in $70 \%$ ethanol for 72 hours with intermittent stirring (Handa et al., 2008). At the end of the process, the extract was passed through Whatman filter paper and the filtrate was collected and further concentrated by evaporating to dryness using distillation apparatus and stored.

\section{Experimental animals}

Male and female Wistar rats of 3 months age, weighing 160-180 g were used. The protocols performed were as per the guidelines of Committee for the Purpose of Control and Supervision of Experiments on Animals (CPCSEA), Government of India. All the protocols explained in the current study were approved by the Institutional Animal Ethics Committee (IAEC) of Vels Institute of Science and Technology (VISTAS), Chennai (Approval number XX/VELS/PCOL/02/2000/CPCSEA/IAEC/01.04.2017). Acute and subacute toxicity studies were performed according to the Organization for Economic Co-operation and Development (OECD) -423 and OECD-407, respectively.

\section{Acute toxicity test}

Lewis Wistar rats were divided into two groups (Group I and II) of six animals (three Males, three Females) each. CULHA at a single oral dose of $2,000 \mathrm{mg} / \mathrm{kg}$ dissolved in distilled water was given to Group II, while the Group I received only distilled water.

After administration of the extract, the animals were monitored daily until 14 days for any toxic signs and general behavioral changes, such as shivers, seizures, difficulty in moving, and sluggishness. At the end of the experimental period, the animals were then sacrificed.

For analysis of hematological and biochemical parameters, blood and serum samples were collected. All the vital organs were stored in $10 \%$ formalin for histopathological examination.

\section{Subacute toxicity test}

According to the OECD-407 guidelines, animals were divided into four groups, each group comprises six animals (three Males, three Females). Three of the groups, namely, Group II,
III, and IV received CULHA at a oral dose of 100, 200, $400 \mathrm{mg} /$ $\mathrm{kg}$ dissolved in distilled water, respectively, while the Group I received only distilled water. Extract or water was administered orally for 28 days; the animals were monitored for toxic signs and general behavioral changes or any other signs of anomaly during the treatment period. At the end of the experimental period, the animals were anesthetized and sacrificed.

For the analysis of hematological and biochemical parameters, blood and serum samples were collected. All the vital organs were stored in $10 \%$ formalin for histopathological examination. Body weight changes were recorded every week until the end of the study.

\section{Clinical signs and body weight measurement}

Before and after dosing, animals were monitored for symptoms of toxicity, including the appearance, possible trauma, and death. Weight change, a key toxicity index for rats, was measured before and after dosing and prior to sacrifice for statistical analysis.

\section{Hematological and biochemical examination}

Blood and serum samples were collected for biochemical and hematological examination. Hematological parameters, such as Red Blood Cell (RBC), White Blood Cell (WBC), Packed Cell Volume (PCV\%), Mean Corpuscular Volume (MCV), Mean Cell Hemoglobin $(\mathrm{MCH})$, and Mean Corpuscular Hemoglobin Concentration ( $\mathrm{MCHC} \%)$ were analyzed immediately. Plasma and serum sample were stored in freezer until analyzed for biochemical parameters.

Biochemical test indices that were studied included: 1) Renal function test (RFT) - Urea, uric acid, creatinine, and Gamma Glutamyl Transferase (GGT). 2) Liver function test (LFT) - total bilirubin, alanine aminotransferase (ALT), aspartate aminotransferase (AST), protein, and Lactate Dehydrogenase (LDH). 3) Other serum parameters-Cholesterol, triglycerides, and glucose.

\section{Histopathological examination}

The heart, liver, spleen, kidneys, and brain of animals $(n=6)$ were collected. The organs were weighed and stored in $10 \%$ formalin. Tissues were subsequently fixed, dehydrated, paraffin embedded. Sections were made about 3-4 $\mu \mathrm{m}$ thick and stained with hematoxylin and eosin for examination under a light microscope (Variya et al., 2015).

\section{Statistical analysis}

Data were presented as mean \pm SD and analyzed by Graph pad prism 5. In acute toxicity groups, mean differences were calculated by a Student $t$-test. Comparison of the mean differences in all the subacute toxicity groups was made using analysis of variance (ANOVA).

\section{RESULTS AND DISCUSSION}

Plant derived products have become unanimously popular, predominantly in the developing countries, and they are presumed to be harmless just for the reason they are a natural source (Vaghasiya et al., 2010). However, there is a lack of scientific proof on the safety of plant material (Ekor, 2014). Therefore, the 
experimental evaluation of the oral toxicity of plants is essential to make sure safety and will help establish the dose ranges for successive efficacy study.

In general, safety studies on herbal extracts are carried out on experimental animals by performing acute and subacute toxicity studies. In the present study, we have evaluated the acute and subacute toxicity of $C$. urens leaf extract in Wistar rats. While the effects of acute toxicity are observed after single dose administration, the effects of subacute toxicity are monitored over 28 days during which there is a repeated exposure to the drug.

\section{General signs and behavior analysis}

The clinical signs and symptoms are the crucial observations to monitor the toxicity effects of drugs on organs (Jothy et al., 2011). In our present study, no treatment related death was observed in animals of both sexes for acute and subacute toxicity studies at the specified oral dose of CULHA. During the 14 (acute) and 28-day (subacute) observation period, animals did not demonstrate any adverse changes in physical behavior, food, and water consumption. No gross or macroscopic abnormalities were observed in all animals of both (acute and subacute toxicity) the groups. Therefore, median lethal dose $\left(\mathrm{LD}_{50}\right)$ of the extract can be considered to be greater than $2,000 \mathrm{mg} / \mathrm{kg}$. Substances having $\mathrm{LD}_{50}>2,000 \mathrm{mg}$ are considered as relatively safe according to Globally Harmonised Classification System (GHS) (Miyagawa, 2010). Hence, CULHA extract can be classified as Category 5 according to GHS.

\section{Effect of CULHA on body weight and organ weight}

Exposure to potentially toxic drug will cause a drastic fall in body weight gain of the rats (Teo et al., 2002). Alterations in body weight and relative organ weight are indicators of toxicity and wellness assessment in experimental animals (El Hilaly et al., 2004; Piao et al., 2013). The body weight of the control and treated rats were shown in Table 1(A-B). In this study, all rats at each dosage group showed sustained weight gain during the experimental periods which indicates that CULHA did not elicit any deleterious effect on body weight in both the acute and subacute toxicity groups. Moreover, no significant difference in the percentage increase of body weight was compared between the treated and control groups.

Relative organ weight (ROW) of the liver, brain, kidney, heart, spleen, and stomach of both the tests were shown in Table 2(A-B). Differences between the ROW of control and treated groups were not statistically important, except for the brain which showed a slight decrease in the ROW of the treated group (subacute toxicity, Group 4) when evaluated against control group. These findings were not considered significant as the changes were toxicologically negligible, and thus it can be established that the administration of CULHA did not elicit any adverse effects to the vital organs.

\section{Effect of CULHA on Hematological parameters}

Hematological parameters have a crucial role in establishing the toxicity induced by the drugs (Petterino and Argentino-Storino, 2006). Alterations in blood parameters have a superior predictive assessment of human safety evaluation, when the data is translated from experiments on laboratory animals (Olson et al., 2000). The hematological results of the control and CULHA treated rats are given in Table 3(A-B).

The reference value for $\mathrm{RBC}, \mathrm{WBC}, \mathrm{PCV}, \mathrm{MCH}$, and $\mathrm{MCHC}$ are $7-10 \times 10^{\wedge 6} / \mu 1,6-18 \times 10^{\wedge 3} / \mu 1,35 \%-64 \%, 14.3-19.5$ $\mathrm{pg}$, and $26.2-40 \mathrm{~g} / \mathrm{dl}$, respectively. In the current investigation, average value of the hematological parameters of both the groups (acute and subacute toxicity study), such as WBC, RBC, PCV, and hemoglobin of the treated groups, were not significantly altered when compared to the control group (Abiola, 2014; Loha et al., 2019). This result suggests CULHA may not have any toxic substances that can lead to conditions like anemia or other abnormalities.

\section{Effect of CULHA on biochemical parameters}

The biochemical evaluations are of vital importance to evaluate safety of drugs on the hepatic and renal function. The data on biochemical parameters of control and treated groups is presented on Table 4(A-B). In this study, all the measured biochemical parameters of the acute and subacute study group did not show any significant changes.

Table 1A. Mean body weight change in the acute toxicity group for 14 days.

\begin{tabular}{ccccc}
\hline Body weight & Day 0 (g) & Day 7 (g) & Day 14 (g) & Total weight gain (g) \\
\hline Group 1 & $165.83 \pm 4.56$ & $172.90 \pm 3.14$ & $190.98 \pm 3.92$ & $25.15 \pm 1.16$ \\
Group 2 & $164.47 \pm 4.80^{\mathrm{NS}}$ & $171.38 \pm 6.26^{\mathrm{NS}}$ & $189.70 \pm 5.54^{\mathrm{NS}}$ & $25.23 \pm 2.66^{\mathrm{NS}}$ \\
\hline
\end{tabular}

Values are expressed as mean \pm SD of six rats in each group. Statistical comparison: Group II versus Group I. Student $t$-test was used to test for significance. No statistically significant difference was observed between test and control groups. For a given dose, NS indicates not significant at $p>0.05$.

Table 1B. Mean body weight change in the subacute toxicity group for 28 days.

\begin{tabular}{ccccccc}
\hline Body weight-Sub acute & Day 0 $(\mathrm{g})$ & Day $\mathbf{7}(\mathrm{g})$ & Day 14 $(\mathrm{g})$ & Day $21(\mathrm{~g})$ & Day 28 $(\mathbf{g})$ & Total weight gain $(\mathrm{g})$ \\
\hline Group 1 & $179 \pm 4.54$ & $186.22 \pm 3.02$ & $209.80 \pm 3.72$ & $215.62 \pm 4.17$ & $226.27 \pm 2.56$ & $47.25 \pm 4.34$ \\
Group 2 & $178.12 \pm 4.55^{\mathrm{NS}}$ & $186.15 \pm 4.40^{\mathrm{NS}}$ & $206.08 \pm 5.86^{\mathrm{NS}}$ & $220.63 \pm 5.87^{\mathrm{NS}}$ & $221.08 \pm 4.41^{\mathrm{NS}}$ & $42.97 \pm 7.67^{\mathrm{NS}}$ \\
Group 3 & $183.35 \pm 4.14^{\mathrm{NS}}$ & $191.63 \pm 5.22^{\mathrm{NS}}$ & $207.23 \pm 5.10^{\mathrm{NS}}$ & $217.68 \pm 6.38^{\mathrm{NS}}$ & $228.32 \pm 3.47^{\mathrm{NS}}$ & $44.97 \pm 4.02^{\mathrm{NS}}$ \\
Group 4 & $182.37 \pm 7.05^{\mathrm{NS}}$ & $192.70 \pm 8.12^{\mathrm{NS}}$ & $208.62 \pm 6.15^{\mathrm{NS}}$ & $221.42 \pm 3.92^{\mathrm{NS}}$ & $229.75 \pm 4.08^{\mathrm{NS}}$ & $47.38 \pm 9.00^{\mathrm{NS}}$ \\
\hline
\end{tabular}

Values are expressed as mean $\pm \mathrm{SD}$ of six rats in each group. Statistical comparison: Group II, III, IV versus Group I. ANOVA and the Tukey test were used to test for significance. No statistically significant difference was observed between test and control groups. For a given dose, NS indicates not significant at $p>0.05$. 
Table 2A. Relative organ weight change in the acute toxicity group.

\begin{tabular}{ccc}
\hline ROW & Group 1 & Group 2 \\
\hline Kidney $(\mathrm{g})$ & $0.62 \pm 0.07$ & $0.63 \pm 0.11^{\mathrm{NS}}$ \\
Spleen $(\mathrm{g})$ & $0.35 \pm 0.04$ & $0.33 \pm 0.04^{\mathrm{NS}}$ \\
Heart $(\mathrm{g})$ & $0.32 \pm 0.04$ & $0.34 \pm 0.04^{\mathrm{NS}}$ \\
Liver $(\mathrm{g})$ & $2.87 \pm 0.27$ & $2.96 \pm 0.21^{\mathrm{NS}}$ \\
Brain $(\mathrm{g})$ & $0.85 \pm 0.17$ & $0.78 \pm 0.07^{\mathrm{NS}}$ \\
Stomach $(\mathrm{g})$ & $0.99 \pm 0.10$ & $0.97 \pm 0.19^{\mathrm{NS}}$ \\
\hline
\end{tabular}

Values are expressed as mean \pm SD of six rats in each group. Statistical comparison: Group II versus Group I. Student $t$-test was used to test for significance. No statistically significant difference was observed between test and control groups. For a given dose, NS indicates not significant at $p>0.05$.

Table 2B. Relative organ weight change in the subacute toxicity group.

\begin{tabular}{ccccc}
\hline ROW & Group 1 & Group 2 & Group 3 & Group 4 \\
\hline Kidney (g) & $0.71 \pm 0.05$ & $0.72 \pm 0.05^{\mathrm{NS}}$ & $0.69 \pm 0.06^{\mathrm{NS}}$ & $0.68 \pm 0.05^{\mathrm{NS}}$ \\
Spleen (g) & $0.31 \pm 0.03$ & $0.32 \pm 0.02^{\mathrm{NS}}$ & $0.31 \pm 0.03^{\mathrm{NS}}$ & $0.33 \pm 0.03^{\mathrm{NS}}$ \\
Heart (g) & $0.28 \pm 0.02$ & $0.29 \pm 0.03^{\mathrm{NS}}$ & $0.29 \pm 0.03^{\mathrm{NS}}$ & $0.28 \pm 0.03^{\mathrm{NS}}$ \\
Liver (g) & $2.76 \pm 0.26$ & $2.91 \pm 0.16^{\mathrm{NS}}$ & $2.77 \pm 0.09^{\mathrm{NS}}$ & $2.57 \pm 0.32^{\mathrm{NS}}$ \\
Brain (g) & $0.87 \pm 0.07$ & $0.77 \pm 0.07^{\mathrm{NS}}$ & $0.79 \pm 0.09^{\mathrm{NS}}$ & $0.72 \pm 0.10^{*}$ \\
Stomach (g) & $0.78 \pm 0.09$ & $0.72 \pm 0.09^{\mathrm{NS}}$ & $0.74 \pm 0.14^{\mathrm{NS}}$ & $0.64 \pm 0.05^{\mathrm{NS}}$ \\
\hline
\end{tabular}

Values are expressed as mean \pm SD of six rats in each group. Statistical comparison: Group II, III, IV versus Group I. ANOVA and the Tukey test were used to test for significance. For a given dose, $*$ indicate a significant difference at $p<0.05$, whereas NS indicates not significant at $p>0.05$.

Table 3A. Hematological parameters of acute toxicity study.

\begin{tabular}{ccc}
\hline $\begin{array}{c}\text { Hematological parameters- } \\
\text { Acute toxicity }\end{array}$ & Group 1 & Group 2 \\
\hline HB $(\mathrm{g} / \mathrm{dl})$ & $13.12 \pm 1.41$ & $13.21 \pm 0.96^{\mathrm{NS}}$ \\
$\mathrm{RBC}(106 / \mu \mathrm{l})$ & $8.17 \pm 0.38$ & $7.97 \pm 0.29^{\mathrm{NS}}$ \\
$\mathrm{WBC}(103 / \mu \mathrm{l})$ & $8.70 \pm 0.39$ & $8.72 \pm 0.30^{\mathrm{NS}}$ \\
PCV \% & $40.71 \pm 1.94$ & $40.17 \pm 2.25^{\mathrm{NS}}$ \\
MCV(fL) & $49.85 \pm 2.45$ & $50.43 \pm 3.09^{\mathrm{NS}}$ \\
MCH(pg) & $16.06 \pm 1.69$ & $16.60 \pm 1.44^{\mathrm{NS}}$ \\
MCHC \% & $32.24 \pm 3.16$ & $33.04 \pm 3.83^{\mathrm{NS}}$ \\
\hline
\end{tabular}

HGB: Hemoglobin, RBC: Red Blood Cell Count, WBC: White Blood Cell Count, PCV: Packed cell volume. MCV: Mean Corpuscular, Volume, MCH: Mean Cell Hemoglobin, MCHC: Mean Corpuscular Hemoglobin Concentration. Values are expressed as mean $\pm \mathrm{SD}$ of six rats in each group. Statistical comparison: Group II versus Group I. Student $t$-test was used to test for significance. No statistically significant difference was observed between test and control groups. For a given dose, NS indicates not significant at $p>0.05$.

Table 3B. Hematological parameters of subacute toxicity study.

\begin{tabular}{ccccc}
\hline $\begin{array}{c}\text { Hematological parameters-Sub } \\
\text { acute toxicity }\end{array}$ & Group 1 & Group 2 & Group 3 & Group 4 \\
\hline HB $(\mathrm{g} / \mathrm{dl})$ & $12.60 \pm 0.77$ & $12.26 \pm 1.65^{\mathrm{NS}}$ & $13.27 \pm 1.78^{\mathrm{NS}}$ & $12.79 \pm 1.16^{\mathrm{NS}}$ \\
$\mathrm{RBC}\left(10^{6} \mu \mathrm{l}\right)$ & $8.22 \pm 0.34$ & $8.10 \pm 0.34^{\mathrm{NS}}$ & $8.58 \pm 0.51^{\mathrm{NS}}$ & $7.99 \pm 0.33^{\mathrm{NS}}$ \\
$\mathrm{WBC}\left(10^{3} / \mu 1\right)$ & $9.20 \pm 1.09$ & $9.14 \pm 0.66^{\mathrm{NS}}$ & $9.03 \pm 0.80^{\mathrm{NS}}$ & $8.04 \pm 0.90^{\mathrm{NS}}$ \\
PCV \% & $40.15 \pm 1.56$ & $40.48 \pm 2.87^{\mathrm{NS}}$ & $39.60 \pm 1.92^{\mathrm{NS}}$ & $39.21 \pm 1.07^{\mathrm{NS}}$ \\
MCV(fL) & $48.91 \pm 2.60$ & $50.08 \pm 4.71^{\mathrm{NS}}$ & $46.41 \pm 4.74^{\mathrm{NS}}$ & $49.18 \pm 2.53^{\mathrm{NS}}$ \\
MCH(pg) & $15.35 \pm 1.07$ & $15.16 \pm 2.22^{\mathrm{NS}}$ & $15.53 \pm 2.24^{\mathrm{NS}}$ & $16.05 \pm 1.71^{\mathrm{NS}}$ \\
MCHC $\%$ & $31.38 \pm 1.39$ & $30.49 \pm 5.17^{\mathrm{NS}}$ & $33.53 \pm 4.26^{\mathrm{NS}}$ & $32.60 \pm 2.47^{\mathrm{NS}}$ \\
\hline
\end{tabular}

HGB: Hemoglobin, RBC: Red Blood Cell Count, WBC: White Blood Cell Count, PCV: Packed cell volume. MCV: Mean Corpuscular, Volume, MCH: Mean Cell Hemoglobin, MCHC: Mean Corpuscular Hemoglobin Concentration. Values are expressed as mean \pm SD of six rats in each group. Statistical comparison: Group II, III, IV versus Group I. ANOVA and the Tukey test were used to test for significance. No statistically significant difference was observed between test and control groups. For a given dose, NS indicates not significant at $p>0.05$. 
Table 4A. Biochemical parameters of acute toxicity study.

\begin{tabular}{|c|c|c|}
\hline $\begin{array}{c}\text { Biochemical } \\
\text { parameters-Acute toxicity }\end{array}$ & Group 1 & Group 2 \\
\hline Cholesterol (mg/dl) & $108 \pm 9.77$ & $105.96 \pm 7.32^{\mathrm{NS}}$ \\
\hline Protein $(\mathrm{g} / \mathrm{dl})$ & $7.57 \pm 0.18$ & $6.87 \pm 0.22 * *$ \\
\hline $\mathrm{TG}(\mathrm{mg} / \mathrm{dl})$ & $115.36 \pm 5.75$ & $122.15 \pm 4.74^{\mathrm{NS}}$ \\
\hline Glucose (mg/dl) & $109.62 \pm 3.18$ & $108.93 \pm 3.41^{\mathrm{NS}}$ \\
\hline Bilirubin(mg/dl) & $0.73 \pm 0.07$ & $0.68 \pm 0.07^{\mathrm{NS}}$ \\
\hline AST (IU/l) & $52.96 \pm 14.76$ & $58.20 \pm 9.48^{\mathrm{NS}}$ \\
\hline ALT (IU/l) & $48.60 \pm 7.99$ & $49.47 \pm 11.35^{\mathrm{NS}}$ \\
\hline LDH (IU/l) & $196.98 \pm 33.44$ & $184.84 \pm 38.79^{\mathrm{NS}}$ \\
\hline Urea $(\mathrm{mg} / \mathrm{dl})$ & $33.05 \pm 2.14$ & $36.45 \pm 2.30^{*}$ \\
\hline Uric acid $(\mathrm{mg} / \mathrm{dl})$ & $4.06 \pm 0.26$ & $4.0 \pm 0.18^{\mathrm{NS}}$ \\
\hline Creatinine (mg/dl) & $0.56 \pm 0.03$ & $0.56 \pm 0.08^{\mathrm{NS}}$ \\
\hline GGT (U/1) & $25.86 \pm 5.84$ & $22.58 \pm 5.61^{\mathrm{NS}}$ \\
\hline
\end{tabular}

Values are expressed as mean \pm SD of six rats in each group. Statistical comparison: Group II versus Group I. Student t-test was used to test for significance. No statistically significant difference was observed between test and control groups. For a given dose, ${ }^{*}, * *$ indicate a significant difference at $p<0.05$ and $p<0.01$, respectively, whereas NS indicates not significant at $p>0.05$.

Table 4B. Biochemical parameters of subacute toxicity study.

\begin{tabular}{ccccc}
\hline $\begin{array}{c}\text { Biochemical } \\
\text { parameters_Subacute }\end{array}$ & Group 1 & Group 2 & Group 3 & Group 4 \\
\hline Cholesterol (mg/dl) & $97.27 \pm 4.71$ & $94.24 \pm 5.71^{\mathrm{NS}}$ & $100.71 \pm 5.24^{\mathrm{NS}}$ & $99.19 \pm 7.30^{\mathrm{NS}}$ \\
Protein (g/dl) & $6.94 \pm 0.78$ & $6.87 \pm 0.65^{\mathrm{NS}}$ & $7.34 \pm 0.35^{\mathrm{NS}}$ & $6.90 \pm 0.88^{\mathrm{NS}}$ \\
TG (mg/dl) & $92.07 \pm 11.60$ & $94.94 \pm 8.30^{\mathrm{NS}}$ & $99.79 \pm 7.99^{\mathrm{NS}}$ & $97.43 \pm 9.14^{\mathrm{NS}}$ \\
Glucose (mg/dl) & $96.15 \pm 5.55$ & $91.12 \pm 7.64^{\mathrm{NS}}$ & $90.30 \pm 10.24^{\mathrm{NS}}$ & $96.89 \pm 5.44^{\mathrm{NS}}$ \\
Protein(g/dl) & $6.94 \pm 0.78$ & $6.87 \pm 0.65^{\mathrm{NS}}$ & $7.34 \pm 0.35^{\mathrm{NS}}$ & $6.90 \pm 0.88^{\mathrm{NS}}$ \\
Bilirubin(mg/dl) & $0.69 \pm 0.04$ & $0.70 \pm 0.08^{\mathrm{NS}}$ & $0.70 \pm 0.10^{\mathrm{NS}}$ & $0.63 \pm 0.12^{\mathrm{NS}}$ \\
AST(IU/L) & $58.20 \pm 6.87$ & $57.91 \pm 4.34^{\mathrm{NS}}$ & $57.04 \pm 6.59^{\mathrm{NS}}$ & $55.87 \pm 7.89^{\mathrm{NS}}$ \\
ALT(IU/L) & $39.58 \pm 4.37$ & $35.50 \pm 9.61^{\mathrm{NS}}$ & $34.05 \pm 4.91^{\mathrm{NS}}$ & $31.43 \pm 4.42^{\mathrm{NS}}$ \\
LDH(IU/L) & $147.06 \pm 23.13$ & $167.3 \pm 31.42^{\mathrm{NS}}$ & $175 . \pm 32.24^{\mathrm{NS}}$ & $170 \pm 24.01^{\mathrm{NS}}$ \\
Urea (mg/dl) & $38.88 \pm 1.38$ & $38.57 \pm 3.39^{\mathrm{NS}}$ & $39.36 \pm 3.91^{\mathrm{NS}}$ & $36.19 \pm 4.42^{\mathrm{NS}}$ \\
Uric acid (mg/dl) & $3.29 \pm 0.35$ & $3.32 \pm 0.28^{\mathrm{NS}}$ & $3.22 \pm 0.42^{\mathrm{NS}}$ & $3.41 \pm 0.43^{\mathrm{NS}}$ \\
Creatinine (mg/dl) & $0.54 \pm 0.02$ & $0.53 \pm 0.10^{\mathrm{NS}}$ & $0.55 \pm 0.05^{\mathrm{NS}}$ & $0.52 \pm 0.08^{\mathrm{NS}}$ \\
GGT (U/L) & $35.71 \pm 4.48$ & $27.99 \pm 3.06^{\mathrm{NS}}$ & $26.63 \pm 6.99^{\mathrm{NS}}$ & $30.11 \pm 6.34^{\mathrm{NS}}$ \\
\hline
\end{tabular}

Values are expressed as mean $\pm \mathrm{SD}$ of six rats in each group. Statistical comparison: Group II, III, IV versus Group I. ANOVA and the Tukey test were used to test for significance. No statistically significant difference was observed between test and control groups. For a given dose, NS indicates not significant at $p>0.05$.

\section{Renal function test}

Measurement of serum uric acid and GGT are used as an classic marker to detect kidney damage, if any (Fuchs et al., 2012). The levels were within the reference range in the present study. Plasma creatinine levels are used to evaluate Glomerular filtration rate (Mpio et al., 2003). The reference value for creatinine is 0.2 to $0.8 \mathrm{mg} / \mathrm{dl}$ (Loha et al., 2019). In this current study, creatinine levels were within the range for both acute and subacute toxicity groups as evidenced by the absence of histopathological modifications in the kidney. Urea is measured as an indicator of kidney function and its level may increase during renal diseases. The level of urea in blood increases as a consequence of decreased urea clearance which occurs during kidney malfunction (Féres et al., 2006). In an adult rat serum, the normal reference range of urea is $15-45 \mathrm{mg} / \mathrm{dl}$ (Loha et al., 2019). In the current investigation, average values of the urea were within the reference range in the subacute toxicity group, but a slight increase in the level of urea was detected in acute toxicity extract treated group. However, the other renal parameters revealed insignificant alterations in the treated groups when evaluated against control demonstrating CULHA has no serious lethal effects on kidney functions.

\section{Liver function test}

Liver is the central drug metabolizing organ and for that reason a prime site for drug related pathologies. Serum enzymes AST and ALT are studied to evaluate liver malfunctions of acute and subacute toxicity group animals. Levels of liver enzyme increase during damage to the liver. An increase in the level of serum bilirubin occurs during breakdown of $\mathrm{RBC}$ or as a result of liver damage (Aba et al., 2014). Levels of LDH are observed to monitor liver damage if any. 
Results of acute toxicity study reveals LDH level of control and treated group were within the reference range. Even though the results of subacute toxicity study indicated a moderate increase in the LDH levels in the treated group when evaluated against the control group, statistical analysis revealed $p>0.05$, which means no significant difference in the average values.

Determining serum protein level is to investigate the secretory and synthetic functional capacity of liver (Ashafa et al., 2012). Dehydration is observed in the case of severe vomiting and diarrhea. Changes in plasma water level due to dehydration caused by lesser water intake can change the concentration of one or more proteins and as a result serum total protein level will be altered. The reference value for serum total protein is 5.6 to $7.6 \mathrm{mg} / \mathrm{dl}$ (Loha et al., 2019). In this study, mean value for serum protein levels were within the reference range for control as well as treated rats in the subacute toxicity group, but a small decrease in the level of protein was observed in acute toxicity treated group. The current investigation revealed that the biochemical parameters of liver (treated group) demonstrated very little difference mostly insignificant when evaluated against the control group.

\section{Other serum parameters}

Lipids and carbohydrates are the major nutrients which play a significant role in different physiological functions of the body. The lipid profile of the acute and subacute toxicity group animals treated with CULHA was assessed by evaluating triglycerides and cholesterol and the levels were found to be within the reference range. Therefore, CULHA extract at all given doses not present any risk for hypercholesterolemia and hypertriglyceridemia (Wang et al., 2010). No significant difference in the blood glucose level was observed in all the groups of both of the sexes, suggesting extract has no hyperglycemic effect. This is also reflected by normal body weight change in both acute and subacute toxicity groups (Al-Goblan et al., 2014).

1A

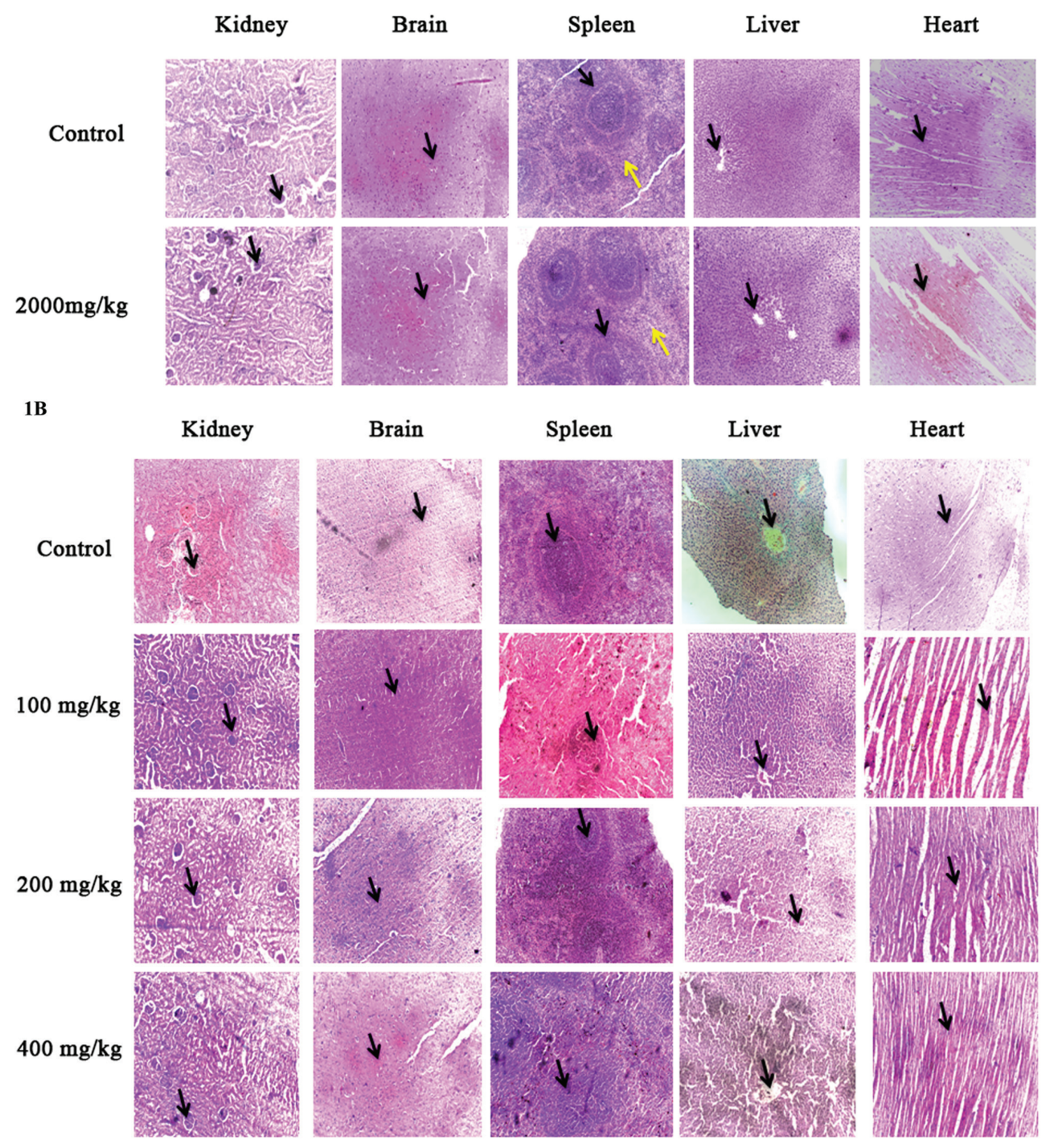

Figure 1. (A) Representative images of liver, kidney, spleen, heart and brain of rats at 40x from control and 2,000 $\mathrm{mg} / \mathrm{kg}$ of CULHA. (B) Representative images of liver, kidney, spleen, heart and brain of rats at 40x from control, 100 $\mathrm{mg} / \mathrm{kg}, 200 \mathrm{mg} / \mathrm{kg}$, and $400 \mathrm{mg} / \mathrm{kg}$ of CULHA. 
Liver and kidney are the major organs implicated in xenobiotic action. While liver is the site of drug metabolism, excretion of drug takes place in the kidney (Unuofin et al., 2018). The results of the LFT, RFT, and other serum parameters, such as lipid profile and blood glucose level, indicate the extract has no aggressive effects on the metabolism or excretion of the products of metabolism.

\section{Histopathological observation}

Historically, histopathology is considered as the most reliable means of establishing the no-observed-adverse effect level (Dorato and Engelhardt, 2005). Histopathological examination of the sections of liver, kidney, heart, brain, and spleen from both sexes of acute and subacute toxicity groups were carried out on the final day of the experiment period and the results are shown in Figure. 1A and B. In this study, none of the organs showed morphologic alteration or any other abnormities in cellular architecture observed under the microscope.

Liver sections of the control and treated group showed normal hepatocytes and portal triad showing prominent central vein. Renal biopsy of the extract treated groups showed normal kidney structure with Bowman's capsules, Proximate convoluted Tubules and Distal convoluted Tubules. The renal biopsy sections of the control group showed normal findings. The brain sections of the treated and the control group shows neurons, glial cells, capillaries that appear normal. Sections of the spleen taken from control and treated group show thin capsule, prominent red, and white pulp. Histopathological examination of the sections of the heart tissue taken from both male and female rats showed normal findings in control as well as treated rats.

\section{CONCLUSION}

In brief, acute toxicity study demonstrated CULHA to have a $\mathrm{LD}_{50}$ value larger than test dose $(2,000 \mathrm{mg} / \mathrm{kg})$. Oral dosage of CULHA (100, 200, and $400 \mathrm{mg} / \mathrm{kg}$ body weight) to Wistar rats for 28 days did not cause treatment related death or side effects in any of the experimental animals. Statistical analysis of the acute and subacute toxicity study groups illustrate there were no considerable changes in the absolute or relative weight of liver, kidney, heart, spleen, and brain. In addition, there were no gross or microscopic anomalies observed in any of these organs. Furthermore, all of the serum biochemical tests carried out on the investigational animals was within the reference range. Thus, no acute or subacute toxicity related effects were seen. This is the first in vivo study on CULHA which reports no risk associated with any of the dosage administered. The results provide important groundwork data on safety profile of $C$. urens which can be a confirmation for the traditional use of $C$. urens in herbal medicine.

\section{CONFLICT OF INTEREST}

Authors declare that they do not have any conflicts of interest.

\section{FINANCIAL SUPPORT}

None

\section{REFERENCES}

Aba PE, Ozioko IE, Udem ND, Udem SC. Some biochemical and haematological changes in rats pretreated with aqueous stem bark extract of Lophira lanceolata and intoxicated with paracetamol (acetaminophen). J Complement Integr Med, 2014; 11:273-7.
Abiola O. Haematological profile shows that Inbred Sprague Dawley rats have exceptional promise for use in biomedical and pharmacological studies. Asian J Biomed Pharm Sci, 2014; 4:33-7.

Al-Goblan AS, Al-Alfi MA, Khan MZ. Mechanism linking diabetes mellitus and obesity. Diabetes Metab Syndr Obes, 2014; 7:587-91.

Arul Ananth D, Sivasudha T, Rameshkumar A, Jeyadevi $\mathrm{R}$, Aseervatham SB. Chemical constituents, in vitro antioxidant and antimicrobial potential of Caryota urens L. Free Radic Antioxidants, 2013; $3: 107-12$

Ashafa AOT, Orekoya LO, Yakubu MT. Toxicity profile of ethanolic extract of Azadirachta indica stem bark in male Wistar rats. Asian Pac J Trop Biomed, 2012; 2:811-7.

Chauhan Gayatri N, Gadhvi R. Caryota Urens-underutilized multipurpose medicinal plant. International Journal of Scientific Research and Reviews, 2018; 8:1942-53.

Deepakkumar R. Kitul Palm ( Caryota urens ): under utilised multipurpose Agroforestry palm and a potential source of jaggery. South Indian J Biol Sci, 2016; 2:344-9.

Dominic C. Toxicological risks of herbal remedies. Paediatr Child Health, 1999; 4:536-8.

Dorato MA, Engelhardt JA. The no-observed-adverse-effectlevel in drug safety evaluations: use, issues, and definition(s). Regul Toxicol Pharmacol, 2005; 42:265-74.

Ekor M. The growing use of herbal medicines: issues relating to adverse reactions and challenges in monitoring safety. Front Neurol, 2014; $1-10$.

El Hilaly J, Israili ZH, Lyoussi B. Acute and chronic toxicological studies of Ajuga iva in experimental animals. J Ethnopharmacol, 2004; 91:43-50.

Féres CAO, Madalosso RC, Rocha OA, Leite JPV, Guimarães TMDP, Toledo VPP, Tagliati CA. Acute and chronic toxicological studies of Dimorphandra mollis in experimental animals. J Ethnopharmacol, 2006; 108:450-6.

Fuchs TC, Frick K, Emde B, Czasch S, Von Landenberg F, Hewitt P. Evaluation of novel acute urinary rat kidney toxicity biomarker for subacute toxicity studies in preclinical trials. Toxicol Pathol, 2012; 40:1031-48.

Hall W. The Kitul Palm : ethnobotany of Caryota Urens L. in Highland Sri Lanka. J Ethnobiol, 1995; 15:161-76.

Handa SS, Khanuja SPS, Longo GRD. Extraction technologies for medicinal and aromatic plants. International Centre for Science and High Technology, Italy, 2008.

Jothy SL, Zakaria Z, Chen Y, Lau YL, Latha LY, Sasidharan S. Acute oral toxicity of methanolic seed extract of Cassia fistula in mice. Molecules, 2011; 16:5268-82.

Loha M, Mulu A, Abay SM, Ergete W, Geleta B. Acute and subacute toxicity of methanol extract of Syzygium guineense leaves on the histology of the liver and kidney and biochemical compositions of blood in rats. Evid Based Complement Altern Med, 2019; 2019.

Miyagawa M. Globally harmonized system of classification and labelling of chemicals (GHS) and its implementation in Japan. Nippon eiseigaku zasshi. Jpn J Hygiene, 2010; 65:5-13.

Moreira DDL, Teixeira SS, Monteiro MHD, De-oliveira ACAX, Paumgartten FJR. Traditional use and safety of herbal medicines. Rev Brasileira Farmacogn, 2014; 24:248-57.

Mpio I, Laville M, Hadj-Aïssa A, Fauvel JP. Predicted creatinine clearance to evaluate glomerular filtration rate in black Caribbean subjects Nephrol Dial Transplant, 2003; 18:1307-10.

Olson H, Betton G, Robinson D, Thomas K, Monro A, Kolaja G., Lilly P, Sanders J, Sipes G, Bracken W, Dorato M, Van Deun K, Smith P, Berger B, Heller, A.. Concordance of the toxicity of pharmaceuticals in humans and in animals. Regul Toxicol Pharmacol, 2000; 32:56-67.

Oyebode O, Kandala N, Chilton PJ, Lilford RJ. Use of traditional medicine in middle-income countries : a WHO-SAGE study. Health Policy Plan, 2016; 984-91.

Petterino C, Argentino-Storino A. Clinical chemistry and haematology historical data in control Sprague-Dawley rats from preclinical toxicity studies. Exp Toxicol Pathol, 2006; 57:213-9. 
Piao Y, Liu Y, Xie X. Change trends of organ weight background data in Sprague Dawley rats at different ages. J Toxicol Pathol, 2013; 26:29-34.

Ranasinghe P, Premakumara GAS, Wijayarathna CD, Ratnasooriya WD. Antioxidant activity of Caryota urens L. ( Kithul ) Sap. Trop Agric Res, 2012; 23:117-25.

Sujitha B, Kripa KG. Comparative evaluation of antioxidant activity and liquid chromatography-mass spectrometry-based phytochemical profiling of various biological parts of Caryota urens. Pharmacogn Mag, 2018; 14:665-72.

Teo S, Stirling D, Thomas S, Hoberman A, Kiorpes A, Khetani V. A 90-day oral gavage toxicity study of D-methylphenidate and D,Lmethylphenidate in Sprague-Dawley rats. Toxicology, 2002; 179:183-96.

Unuofin JO, Otunola GA, Afolayan AJ. Evaluation of acute and subacute toxicity of whole-plant aqueous extract of Vernonia mespilifolia Less. in Wistar rats. J Integr Med, 2018; 16:335-41.

Vaghasiya YK, Shukla VJ, Chanda SV. Acute oral toxicity study of pluchea arguta boiss extract in mice. J Pharmacol Toxicol, 2010; 6: $113-23$.
Variya BC, Patel SS, Trivedi JI, Gandhi HP, Rathod SP. Comparative evaluation of HMG CoA reductase inhibitors in experimentallyinduced myocardial necrosis: Biochemical, morphological and histological studies. Eur J Pharmacol, 2015; 764:283-91.

Varshney P, Suresh S. A critical review of emergence of the ayurvedic tradition in vedic literature. Int J Sanskrit Res, 2015; 1:24-7.

Wang X, Zhang W, Wang Y, Peng D, Ihsan A, Huang X,Yuan $\mathrm{ZH}$. Acute and sub-chronic oral toxicological evaluations of quinocetone in Wistar rats. Regul Toxicol Pharmacol, 2010; 58:421-7.

Woo CSJ, El-Nezami H. Herbal hepatotoxicity. Toxicol Herb Prod, 2017; 43:271-305.

\section{How to cite this article:}

Balaji S, Ganesan KK. Acute and subacute toxicity evaluation of hydroalcoholic extract of Caryota urens leaves in Wistar rats. J Appl Pharm Sci, 2020; 10(04):121-128. 